\title{
THE APPLICATION OF THE AMNESTY IN THE REPUBLIC OF UZBEKISTAN: PRACTICAL AND THEORETICAL ISSUES
}

\author{
Fayzullokhon Dumaev, \\ The teacher at National University of Uzbekistan
}

http://dx.doi.org/10.26739/2573-5616-2018-3-1-9

\begin{abstract}
This article is devoted to clarify the significance of application of the act of amnesty in accordance with humanitarian principles and the lawful situation of people on whom the act is being granted, the essence of protection of subjective rights of the victim, the advanced experience of foreign countries and the current changes those have been taking place in our country. The suggestions and conclusions given in the article are considered to be the result of the scientific research of the author that they are focused on perfection of standard documents directed to the regulation of social attitudes.

Key words: Amnesty, punishment, to put in jail, humanitarianism, the court, incarceration, convict, social adaptation, the victim, pardon, Amnesty International, social help, the act of amnesty, the document of amnesty, the sentence.
\end{abstract}

$T$ The amnesty is considered to be a stimulating document which indicates that the human, its rights and liberty are of supreme virtue in our country that has been walking through the path of construction of civil society. For instance, thousands of families feel on cloud nine through this act. The deep gist of this act is also meant to providing the aim through not punishing the guilty with the punishment. Therefore, as our President Shavkat Mirziyoyev stated in his speech for the $25^{\text {th }}$ anniversary of the Constitution of the Republic of Uzbekistan, one of significant issues any kind of government claiming of being a humanitarian state faces is to give one more chance to the people who had confusedly entered the path of law breaking and committed, have been deeply sorry for the evil deed they did, to send them back to their families. One thing that should be noted is that, they are also citizens of the country[1].

The first aim of the adoption of the act of amnesty is the fulfillment of humanitarian principle in reality in the state and in the society. First of all, the adoption of amnesty does not consider only the benefits of convicts or people who committed crime, but it also means their family members, close and remote relatives, their immature children should feel affection 
towards them by the person being sentenced, similarly, it also considers the huge position of a father or a mother who is responsible for the development of either spiritual or economical atmosphere, putting the benefits of society into consideration, the amnesty is granted that it clearly reflects the affectionate idea of a country towards its society members. One thing should be noted here that even though a certain positive experience and practice towards the application of the act of amnesty have been formed by the courts, during the application of the law application process has been facing some problems. These concerns, first, have been arising because of need to further advancement of law in the field and lack of researches into the institution of amnesty.

The President of our country Shavkat Mirziyoyev specifically paid attention to this matter at the $25^{\text {th }}$ anniversary ceremony of the declaration of the Constitution of the Republic of Uzbekistan, when he made a speech, he pointed out the followings.., and "I am going to thoroughly point out one thing now. It is not secret that people who are far away from the juridical field cannot differentiate the terms of amnesty and pardon. All of us are well informed that every year our country would grant several acts of amnesty. The main content of the amnesty is that it marks the type of the commitment first, and then people who are categorized to be in this type are marked. Surely, the amnesty is one of the most important mechanisms of forgiving people who have committed crime. However, the analysis have shown that setting free from the punishment without thinking deeply may lead to the inclusion of a person who has not truly understood his mistake and has not completely covered his loss yet into the circle of amnesty. In this matter, thousand regrets, it might be mentioned that the cases of corruption also have happened. The offices of the public prosecutor, internal affairs and the department of the court also have also undergone such a repulsive deed. This, in turn, has let such people not to feel the punishment, and the feeling of everything to be acceptable for them has been wrongly developed in their minds. The worst is that the opinion of neither victim nor the public has not been put into consideration, and this has been resulting of with the fair protest of the citizens. For this reason, with regrets, recommitment of crime by people who have formerly been granted with amnesty has also been encountered"[2].

A Russian researcher O.V. Semenova on her dissertation named "Амнистия по законодательству России и стран-участниц СНГ уголовно-правовой и криминологический аспекты" for PhD stopped at the problematic aspects of the matter that she made the following comments.., "No any kind of legal institution has not so widely covered both the members of society and the representatives of juridical line as the institution of amnesty during the past recent years. In the years from 1999 
to 2005 only, nearly ten amnesty acts have been adopted by the State Dumas that according to them 259893 people were set free from the punishment of jail, 112685 people were set free from the reminder period of jail, 772068 people were set free from the punishment not related to the jail.., The aim of application of amnesty is to follow the demands of democracy, together with to reach the social justice, it also focuses on preventing people from recommitting crime and to thoroughly explain that there is a clear punishment for the evil deed. However, since the amnesty that were granted could not fight against the existing problems and matters, the cases of criticize by the members of society have been faced"[3] she stated.

In our point of view, granting the amnesty to the person who has not fully confessed his fault and putting the conclusion to the whole crime case is incorrect, to our knowledge. Furthermore, the adoption of amnesty acts which are done every year might have been handy for those who have committed crimes and hiding themselves from the court and interrogation waiting for the adoption of the next act of amnesty which would probably protect them from the punishment, and this arises a fair question concerning whether this act has been benefiting for such corrupt people or for those who have unconsciously committed the crime. Similarly, there is no doubt that people, who have not been fully aware of their fault even though they attend the trials and interrogation, may surely committed another crime un the future. The lawyer X.D.Alikperov of Russia has mentioned followings in his research work, "If the person does not confess his fault, the feeling of being truly sorry from the bottom of heart does not occur either"[4]. The clear evidence of this is the commitment of crime by people who had formerly been granted with the act of amnesty and set free from the responsibility. It should be stated as an example that the neighboring country the Republic of Turkmenistan tries to prevent the commitment of crime by people who had been formerly granted with the act of amnesty setting them from the punishment, the country passed a law and on $316^{\text {th }}$ article of Crime-Procession Code second part states that "If the people who had been formerly granted with the act of amnesty commit a new crime within a year, the case serves as the restoration of the formerly ended crime case (when the period of sentencing has not been finished yet)"[5] which makes everything clear.

Even though a group of scientists have conducted several researches into the application of amnesty on the stage of process of crime, among them juridical sciences candidate B.B.Murodov in his monograph work "The close of crime case: theory and practice" gives the suggestions and considerations of application of amnesty act on the stage of crime process of crime case based on the comparative analysis of social polls that he 
contributed to the development of the field. For instance, according to the statement of the researcher different kinds of misunderstandings have been occurring on granting amnesty act by interrogation and court as a result of some troublesome situations. For instance, the person named B. who had committed a crime whose social danger is not so great was granted with amnesty in 2010 with appropriately following to the current laws. However, the department of interrogation latterly in the year of 2012 found out that B. had committed very serious crime in the year of 2008 too. Naturally, if the serious crime committed by B in 2008 had been exposed on time, he would have been granted with the act of amnesty in the year of 2010. The question arises here: Should the act of amnesty that was granted to B. in the year of 20010 be canceled? The analysis of result of poll indicates that a certain case might be approached differently on both interrogation and trial stage. In our point of view, in this case we should apply the $523^{\text {rd }}$ article of the CPC and $64^{\text {th }}$ article of CC that the agreement of court on the act of amnesty should be cancelled, and as the second group has mentioned, all the crime cases committed by a person under the name of B. should be gathered into one single crime case unit, afterwards, a new interrogation should be conducted as it would have been the most optimal way[6].

The members of the Senate of the Supreme Assembly of the Republic of Uzbekistan on the matters of trial-law and the Legislative Chamber of the Senate of the Supreme Assembly of the Republic of Uzbekistan, The head interrogation office of the Republic of Uzbekistan, the Constitutional court, the Supreme court, the representative of Supreme Assembly on human rights (ombudsman), the Chamber of Ministers, the ministries of Internal affairs, Labor, Healthcare, Foreign affairs, Justice, the charity social fond of "Mahalla", the current institution in charge of the monitoring of the implementation of the laws under the cabinet of the President of the Republic of Uzbekistan, the members of the national center of the Republic of Uzbekistan on human rights were read the result of the implementation of the Resolution of the Senate "On the amnesty act on the behalf of the $24^{\text {th }}$ anniversary of the declaration of the adoption of the Constitution of the Republic of Uzbekistan" by the deputy of the Head public prosecutor of the Republic of Uzbekistan at the conference on January 25,2017. As it was noted in the announcement, the Resolution on Amnesty has been granted to 39748 people in total to the state of January 13, 2017, 26265 of them were set free from criminal and financial punishments. For instance, the Resolution on Amnesty granted to 5408 women, 893 people who are teenagers, and 410 foreigners. In accordance with the second part of the resolution 15678 people who had committed crime as a result of being careless, similarly, those who committed crime whose social danger is not so serious or those who were sentenced for 
committing minor crime consciously for the first time were set free from the punishment. Similarly, the period of sentence to spend some period of life in the prison of 13483 people had their period shortened in accordance with the sixth part of the Resolution on Amnesty[7].

It would have been fair to put an emphasis to the positive sides of the act of amnesty in international scale. There is a unique role and position of Amnesty International on preventing going bloody wars in some continents, signing peace treaties between the sides which are fighting, preventing the people who have confusedly joined in these forces from their way, establishing peace in the lands where the civil wars and troubles have been going on. The Russian researcher D.V.Kokhman who has been conducting a research work in this field stated the followings.., "If one of the duties of the act of amnesty is founded on humanitarianism, the other duty of this act is to correct the errors which were inattentively made by the court, this act also positively impacts on the spirituality of not only the person who has been truly sorry for his wrong deed, but to his family members' also, similarly, it also helps to decrease the particles on the department of right reserving, to save up the finance which would have spent on keeping the convict in the prison, if the amnesty had been granted by a single states formerly, currently Amnesty International has been focused on forgiving people who have take part in civil wars based on wide scale international experience, the Amnesty International is granted basing on international legal demands by international establishments"[8].

There are not only differences in understanding the essence and significance of the act of amnesty in our country by the citizens; similarly, the professionals who have been serving in this field also have various views towards the original meaning of the institution. For instance, C.Ortikova thinks that the amnesty is a general pardon that it is the private act of supreme government departments, it is the resolution about to set some people free from the punishment, to cancel the crime case or to enlighten the punishment[9]. To set free with the act of amnesty means that the setting a person who has committed an action which can be counted as a crime free from crime punishment, setting the guilty free from main and additional punishment[10]. These definitions clearly indicate that when S. Ortikova interprets the amnesty as a resolution, Sh. Berdiev refers to it as an act, in how should it be interpreted correctly in reality? On the second line of the first part of the $84^{\text {th }}$ article of the Crime Procession Code of the Republic of Uzbekistan, in other words, "if the act of amnesty which has been announced is related to the person who committed the crime or to the crime which was committed" and this Code's $63^{\text {rd }}$ chapter's naming "Application of the amnesty on the pre-trial stage" and in other several norms the term of "act" has been used. However, on the documents 
being adopted by the Supreme Assembly of the Republic of Uzbekistan related to the amnesty uses the term "resolution". This case was mentioned as "the documents about amnesty[11]" on the $80^{\text {th }}$ and $93^{\text {rd }}$ articles of the Constitution of the Republic of Uzbekistan. The national encyclopedia of Uzbekistan authored by M.Aminov, B.Ahmedov, H.Boboev and others states that "act" means an important official document which confirms the event, occurrence, activity or certain work, juridical fact whereas the word "resolution" means a certain decision, pact, a firm thought which must be completed, conclusion, a certain work, matter, the instruction which was made thoughtfully or the agreement of an official organ, establishment on a certain work adopted with consultation. In this definition, the reference of the document of amnesty in the form of "resolution" in the norms of CPC is correct in content. In addition, in accordance with the $7^{\text {th }}$ article of the law "On the Senate of the Supreme Assembly of the Republic of Uzbekistan", "the Senate may come up with declarations and proclamations on common humanitarian, social economical and other matters, they are legalized with the resolution of the palate"[12]. Considering the fact that the Senate does not adopt a document in the content of "act", it would have been in accordance with the legislative technique if the word "act" had been changed with the term "resolution" on the $29,36,46,48,84,342,351,355,372,382,385$, $463,536,542,573^{\text {rd }}$ articles of CPC, and on the $63^{\text {rd }}$ chapter.

Any kind of resolution on amnesty is made up the principle of humanitarianism that there is the persuasion to forgive people who committed crime. For this reason the state departments should adopt the document on amnesty in accordance with political, economical purpose, and the implementation process needs to be modified. Although the restoration of the rights of the victim through the documents of amnesty which have been adopted is considered to be one of the main tasks of the crime process, current CPC does not mark the recover of the loss to the victim as an obligatory requirement of the application to this fundament. This is the reason why so many appeals have been made by the victim to the application of the amnesty document on the defendant that the addition of the norm of coverage of loss that was resulted to the CPC on the application of amnesty act will serve to prevent the dispute and deliberation.

It should be stated as a conclusion that, the amnesty is considered to be a legal-normative document that it has the following features:

- It can impact on the rights and benefits of the people within certain limits from the moment it was granted without adding changes and additions to the laws which are on implementation;

- It does not have to be canceled with special legal norm that it will naturally stop from the activity as time passes;

- It does not contain the new elements of legal regulation. 


\section{References}

1. The Constitution is the strong fundament of our liberal and plentiful life, and further development of our country. From the speech of President Shavkat Mirziyoyev at the $25^{\text {th }}$ anniversary of declaration of the Constitution of the Republic of Uzbekistan/ / The Xalq so'zi tabloid. The issue on $8^{\text {th }}$ of December, 2017.

2. Mirziyoyev Sh.M. The constitution - the strong fundament of our liberal and plentiful life, further development of our country// The lecture for the festive 25th anniversary of the declaration of the Constitution of the Republic of Uzbekistan.

3. O.V. Semenov. Amnesty under the legislation of Russia and CIS countries: criminal law and criminological aspects // Abstract. dis. .... Cand. jurid. sciences. - Ryazan., 2005. - 8 p.

4. Kh.D. Alikperov Exemption from criminal liability. - Voronezh., 2001.-P.20-23.

5. Crime-Procession Code of the Republic of Turkmenistan (Adopted on May 3, 2008)

6. B.B.Murodov M 91. Closing the crime case: theory and practice: Monography. ? T.: AIA of the Republic of Uzbekistan, 2016. - P. 81.

7. The application of the act of Amnesty is under the control of the parliament // 25.01.2017 http:// senat.uz/uz/news/2017/25-01.html

8. Д.В.Кохман. Амнистия в целях восстановления мира и возможность ее применения для российких граждан в сирийском конфликте // Современное право, № 1. 2017. Г. 105-c.

9. S. Ortikova Amnesty ? the expression of generosity// Huquq va burch. - 2013. -№1. P.2-3.

10. Berdiev Sh. The issues of modifications of setting free from the crime punishment on the process of liberalization of laws related to the crime: Doctor of judicial sciences. dis. - T., 2011. - P. 13.

11. The informative of the Supreme Council of the Republic of Uzbekistan, the year of 1994., 1st issue, 5th article; the Informative of the Supreme Council of the Republic of Uzbekistan, the year of 2003., 3-4 issue, 27 ${ }^{\text {th }}$ article; The informative of the palates of the Supreme Assembly of the Republic of Uzbekistan, the year of 2011., 12/1 issue, $343^{\text {rd }}$ article; The collection of law of the Republic of Uzbekistan, the year of 2007., $15^{\text {th }}$ issue, $152^{\text {nd }}$ article; the year of 2008., 52 $2^{\text {nd }}$ issue, $510^{\text {th }}$ article; the year of 2011., $16^{\text {th }}$ issue, $159^{\text {th }}$ article; the year of 2014., $16^{\text {th }}$ issue, $176^{\text {th }}$ article; the year of 2017., $14^{\text {th }}$ issue, $213^{\text {th }}$ article, $22^{\text {nd }}$ issue, $406^{\text {th }}$ article, 35th issue, 914 ${ }^{\text {th }}$ article)

12. The national database of law documents, 10.01.2018., 03/18/459/0536 issue. 